\title{
EVOLUTION OF BLACK SHALE FORMATIONS AND RELATED HYDROCARBONS GENERATION WITHIN THE ANCIENT CONTINENTAL MARGIN OF TETHYS (UKRAINIAN CARPATHIANS AND ADJACENT TERRITORIES) \\ Y.V. Koltun
}

\author{
ЕВОЛЮЦІЯ ЧОРНОСЛАНЦЕВИХ ТОВЩ ТА ГЕНЕРАЦІЯ ВУГЛЕВОДНІВ В МЕЖАХ \\ ДАВНЬОÏ КОНТИНЕНТАЛЬНОÏ ОКРАÏНИ ТЕТІСУ \\ (УКРАÏНСЬКІ КАРПАТИ ТА СУМІЖНІ ТЕРИТОРІї) \\ Ю.В. Колтун
}

In the sequence of the continental margin of Tethys in the Carpathian region within the age range from Vendian to Miocene occur several organic-rich formations. Geochemical investigations of rocks allowed distinguishing the potential petroleum source rocks, to trace their geochemical and thermal evolution from sedimentogenesis to catagenesis and to estimate the depths range of possible hydrocarbon generation.

Key words: organic matter, genetic type of kerogen, oil-generation potential, thermal maturity, hydrocarbons generation.

В розрізі континентальної окраїни Тетісу в межах Карпатського регіону у віковому діапазоні від венду до міоцену міститься ряд товщ, збагачених розсіяною органічною речовиною. Геохімічні дослідження порід дозволили виділити потенційно нафтогенеруючі товщі, прослідкувати їх геохімічну та термальну еволюцію від седиментогенезу до катагенезу та оцінити діапазон глибин можливої генерації вуглеводнів.

Ключові слова: органічна речовина, генетичний тип керогену, нафтогенераційний потенціал, термальна зрілість, генерація вуглеводнів.

Карпатський складчастий пояс та прилеглі території Європейської платформи є комплексом давніх континентальних окраїн Палео-, Мезо-, Нео- і Пара-Тетісу, що послідовно змінювали одна одну в межах цього регіону. В літологічному літописі відображена складна взаємодія тектонічних, океанологічних, біогеохімічних та інших подій, що формували геологічну будову регіону протягом цього обширного часового інтервалу. Метою даної роботи є виділення в розрізі основних товщ, збагачених розсіяною органічною речовиною, подати їх геохімічну характеристику, оцінку нафтогенераційного потенціалу та можливості його реалізації в ході еволюції цих відкладів від стадії седиментогенезу до сучасного їх стану (катагенез).

Утворення цих товщ стало наслідком давніх безкисневих подій як глобального, так і регіонального масштабів, що спричинили формування потужних чорносланцевих розрізів. Найважливішими з них є: калюські верстви (миньковецький горизонт) венду середнього Придністров'я, кембрій-силурійські відклади, що поширені у фундаменті Передкарпатського прогину, барем-альбські та олігоцен-міоценові товщі карпатського флішу. Ці відклади становлять особливий інтерес, оскільки вони є потенційно нафто-газогенеруючими товщами і їх геологічне та геохімічне вивчення має важливе значення для оцінки перспектив нафтогазоносності регіону.

Прикладом докембрійської чорносланцевої товщі, що вважаємо відображенням в межах південно-західної окраїни Східно-Європейської платформи певного масштабу безкисневої події, є відклади миньковецького горизонту вендського віку. Область поширення цих відкладів охоплює ВолиноПодільську монокліналь, Північно-Молдавське підняття і західну частину Молдавської монокліналі. Утворення цієї товщі проходило під впливом апвелінгу [8], про що свідчить не тільки підвищена кількість розсіяної органічної речовини в породах, а й висока концентрація фосфатної речовини, зокрема, наявність кулеподібних фосфоритових конкрецій.

Потужні товщі аргілітів та алевролітів нижнього палеозою (кембрій-силур), збагачені розсіяною органічною речовиною, що поширені вздовж давньої континентальної окраїни Палео-Тетісу, ймовірно представляли відклади глибокої частини шельфу, що нагромаджувались в умовах безкисневого седиментогенезу.

Барем-альбські чорносланцеві відклади шипотської та спаської світ, що залягають в основі розрізу карпатського флішу, є відображенням в літологічному літописі Карпатської частини Мезо-Тетісу глобальної апт-альбської безкисневої події [11], яка охоплювала значну частину Світового океану. 


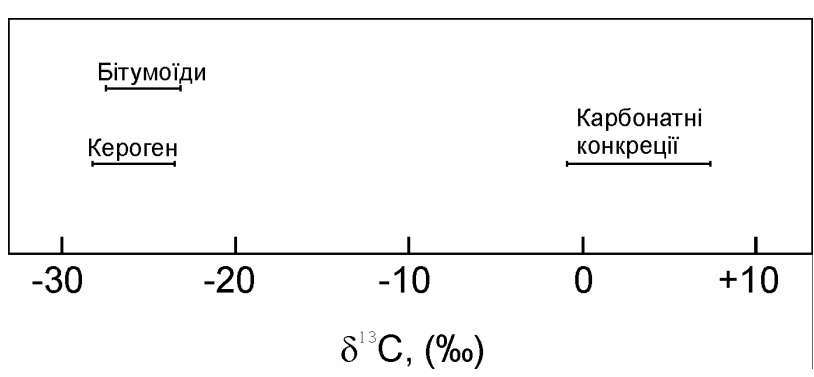

Рис. 1. Склад стабільних ізотопів вуглецю в керогені і бітумоїдах аргілітів та в карбонатних мінералах діагенетичних конкрецій менілітової світи Українських Карпат

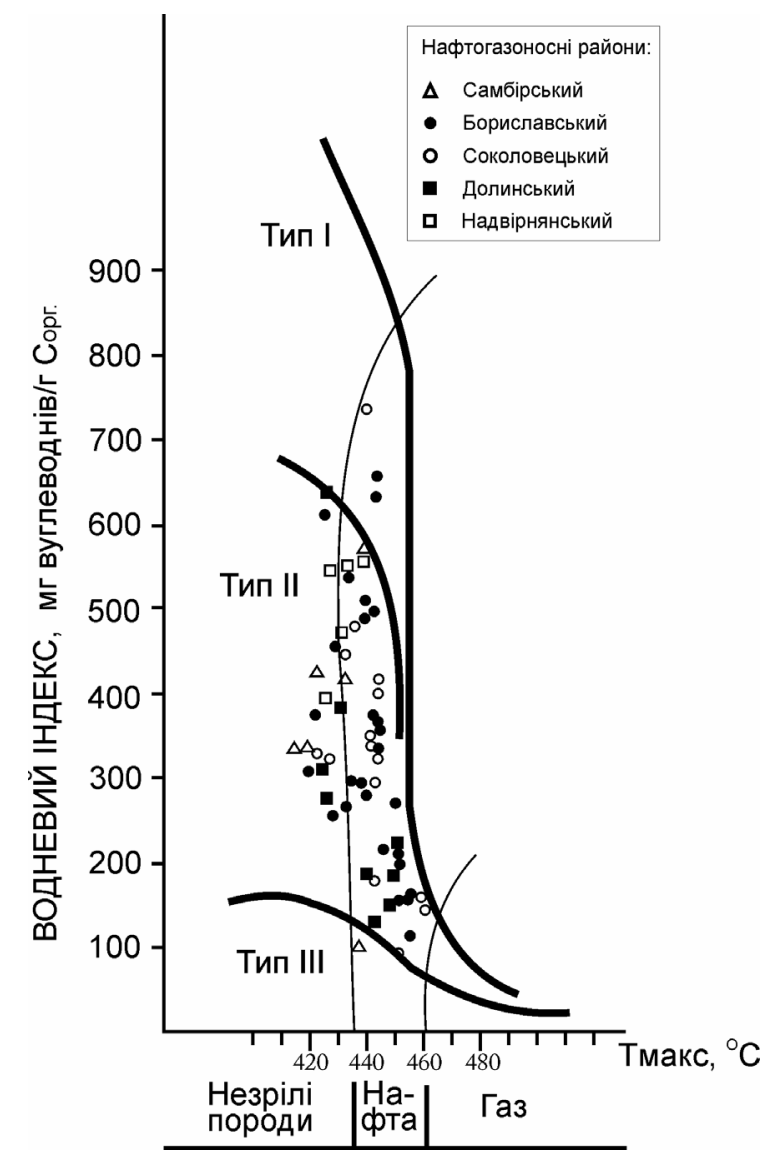

Рис. 2. Діаграма водневий індекс (HI) - температура піролізу при максимальному виході продуктів крекінгу керогену (Тмакс.) для порід менілітової світи зовнішніх тектонічних зон Українських Карпат
Чорносланцеві відклади олігоценового-ранньоміоценового віку хоча і не мають глобального поширення, охоплюють значні території і їх утворення було результатом широкомасштабної регіональної безкисневої події в Нео- і ПараТетісі. В Карпатському басейні це спричинилося до нагромадження потужної чорносланцевої товщі менілітової світи. Дана безкиснева подія була пов'язана з існуванням середньоглибинного шару кисневого мінімуму [4], що виник у товщі вод в результаті інтенсивної поставки органічної речовини із зони апвелінгу [2, 6, 7].

Як відомо, одними із визначальних факторів для формуванні потенційно нафтоматеринських порід $€$ вміст органічної речовини та її генетичний тип. Обидва фактори обумовлюються палеоокеанографічними умовами на стадіії седиментогенезу. Всі названі вище чорносланцеві товщі формувалися в морських басейнах в умовах, що сприяли активній седиментації органічної речовини в основному морського походження і їі ефективній фосилізації, а отже забезпечували високу концентрацію в осадах потенційно нафтогенеруючої органічної речовини.

Діаненетичні перетворення органічної речовини відбуваються в основному завдяки біохімічним процесам і саме на цій стадії формується вихідний нафтогенераційний потенціал порід.

Відклади менілітової світи олігоцену, що завершують розріз флішу Карпат, $є$ основною нафтоматеринською товщею досліджуваного регіону $[5,10]$, тому на цих відкладах зупинимося дещо детальніше. Вміст $\mathrm{C}_{\text {орг. }}$ в чорних аргілітах менілітової світи в більшості випадків знаходиться в межах від 4 до 8\%, досягаючи в окремих місцях понад 20\%. Анаеробний режим в осадах, який створився в результаті переважання рівня споживання кисню над його надходженням, не тільки забезпечував ефективне захоронення органічної речовини, але й визначав хід її подальшої деградації. Власне тоді, на стадії раннього діагенезу, під впливом активних мікробіологічних процесів, проходило подальше формування хімічного складу, а отже і нафтогенераційного потенціалу відкладів. Ізотопні дослідження цих порід [3] показали (рис. 1) збагачення діагенетичних карбонатних конкрецій важким ізотопом

вуглецю ( $\delta^{13} \mathrm{C}$ від -0.9 до $+7.4 \%$ ), що вказує на інтенсивність біохімічних процесів при діагенетичній трансформації органічної речовини на стадії бактеріального метаногенезу. Органічна речовина характеризується легким ізотопним складом і подібними діапазонами $\delta^{13} \mathrm{C}$ для керогену (від -23.5 до $-28.2 \%$ ) і бітумоїдів (від - 23.1 to $-27.5 \%$ ), що свідчить про те, що вона в значній мірі складається 3 продуктів перетворення морського планктону з домішкою залишків наземної рослинності. Результатом переробки органічної речовини анаеробними мікроорганізмами було руйнування ізотопно важ- 
кої білково-вуглеводневої фракції, полімеризація ліпідного матеріалу і збагачення осадків біомасою мікроорганізмів, а отже підвищення нафтогенераційного потенціалу вихідної органічної речовини.

Вміст загального органічного вуглецю $\left(\mathrm{C}_{\text {орг }}\right)$ в чорних аргілітах шипотської світи досягає 8\%, складаючи в більшості випадків від 2 до 4\%. Аналогічні породи спаської світи вміщують, як правило, більше $2 \%$, в окремих випадках - понад $7 \% \mathrm{C}_{\text {орг. }}$ І Ізотопні дослідження органічної речовини та карбонатних конкрецій нижньокрейдових відкладів шипотської і спаської світ [1] вказують на активні процеси бактеріальної сульфат-редукції на стадії діагенезу, а отже про ефективне формування нафтогенераційного потенціалу порід в анаеробних умовах.

Геохімічні параметри та хід термального дозрівання згаданих вище чорносланцевих відкладів вивчались за допомогою піролізу Rock Eval [9].

Відклади менілітової світи найширше розвинуті в межах Внутрішньої зони Передкарпатського прогину та зовнішньої частини Скибової зони. Тут вони досягають найбільшої потужності і найвищого вмісту загального органічного вуглецю і саме тут зосереджені основні поклади нафти Карпатської нафтогазоносної провінції. Тому геохімічні характеристики цих порід вивчались найбільш детально.

Параметр S2 - нафтовий потенціал, являє собою кількість вуглеводнів, що утворюються в процесі крекінгу керогену. Цей параметр дозволяє розпізнати нафтоматеринську товщу в розрізі і оцінити їі нафтогенераційні можливості. Величини цього параметру в досліджуваних зразках порід менілітової світи знаходяться в межах 2,33-49,6 мг вуглеводнів/г породи. Згідно з класифікацією [9] переважна більшість зразків характеризується хорошим і дуже хорошим нафтогенераційним потенціалом.

Інші параметри піролізу дозволяють оцінити генетичний тип органічної речовини та ступінь її термальної зрілості.

На рис. 2 показана діаграма водневий індекс (HI) - температура піролізу при максимальному виході продуктів крекінгу керогену (Тмакс.), на якій відображено результати дослідження зразків порід менілітової світи різних нафтогазоносних районів Внутрішньої зони Передкарпатського прогину. Діаграма показує, що переважна кількість досліджуваних зразків порід вміщує кероген типу II, згідно 3 класифікацією [9]. Органічна речовина типу II нагромаджується в морських осадах. Вихідним матеріалом для неї є фітопланктон і біомаса мікроорганізмів, часто з домішкою залишків вищої наземної рослинності. Фосилізація органічної речовини відбувається у відновному середовищі. Органічна речовина типу II $€$ потенційно нафтогенеруючою і характерна для більшості нафтоматеринських порід. Діаграма також показує, що термальна зрілість досліджуваних зразків знаходиться в діапазоні від незрілих порід до нижньої межі зони утворення нафти.

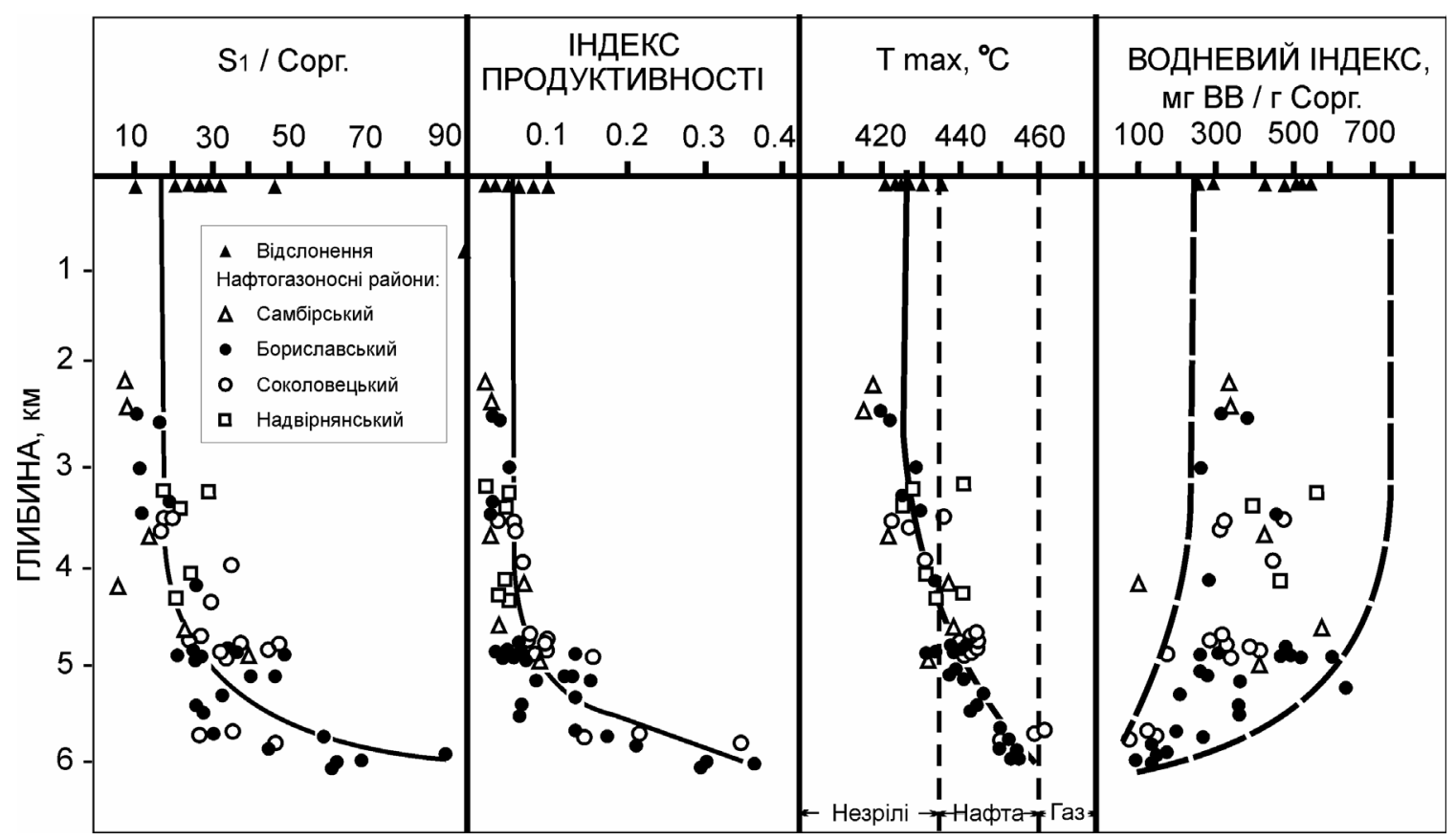

Рис. 3. Графік зміни параметрів піролізу з глибиною для порід менілітової світи зовнішніх тектонічних зон Українських Карпат 


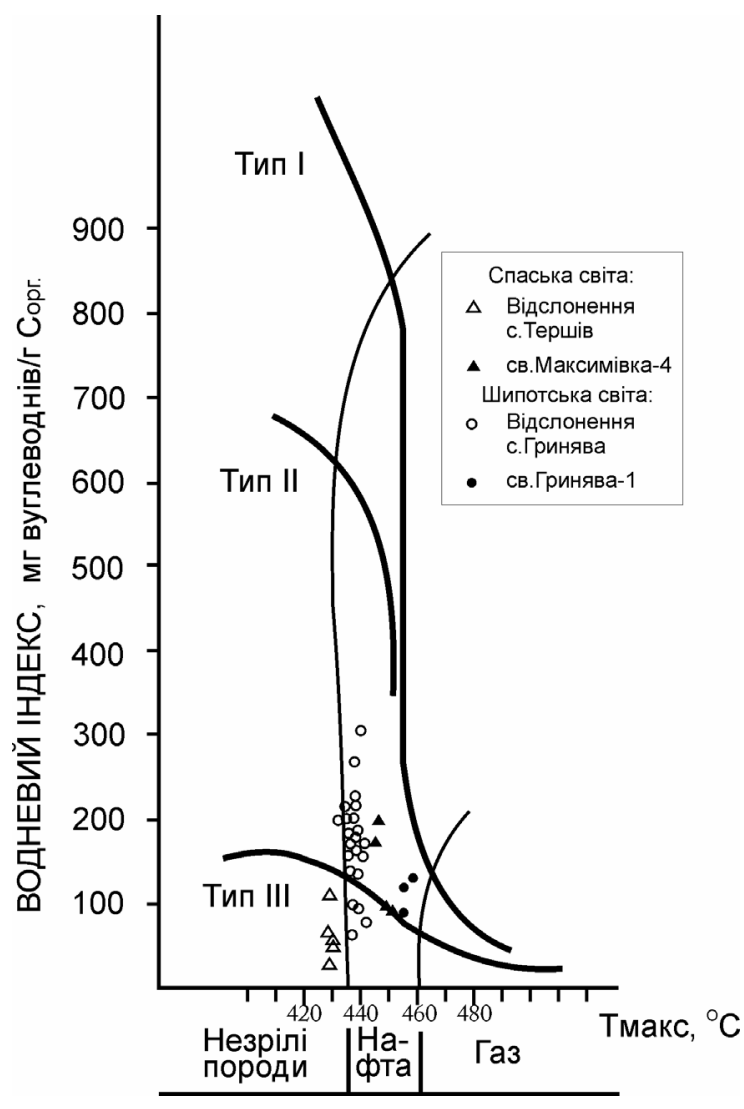

Pис. 4. Діаграма водневий індекс (HI) - температура піролізу при максимальному виході продуктів крекінгу керогену (Тмакс.) для нижньокрейдових порід (шипотська і спаська світи) Українських Карпат
Рис. 3 демонструє еволюцію з глибиною ряду параметрів піролізу для порід менілітової світи зовнішніх структурно-тектонічних зон Українських Карпат. Досліджений діапазон глибин залягання цих порід поширується від денної поверхні до максимальних розкритих бурінням (понад 6 км). Дослідженням охоплені всі основні нафтовидобувні райони. Порівнюючи результати по чотирьох різних параметрах, показаних на рис.3, можемо переконатись, що вони демонструють одну і ту саму тенденцію зміни з глибиною, яка дозволяє охарактеризувати еволюцію процесу генерації вуглеводнів породами менілітової світи по мірі зростання ступеня катагенетичної перетвореності порід. Згідно з одержаними даними, органічна речовина цих порід залишається термально незрілою в інтервалі глибин від поверхні до приблизно 4,5км. На глибині 4,5 км породи вступають в зону утворення нафти i, починаючи з цієї глибини, активізуються процеси генерації в породах рідких вуглеводнів. Різко зростає кількість вільних вуглеводнів в породах (параметр S1) та індекс продуктивності. Температура піролізу при максимальному виході продуктів крекінгу керогену демонструє, що породи залишаються термально незрілими від поверхні до глибин близько 4,5 км. Величина цього параметру починає закономірно зростати при досягненні породами верхньої границі нафтового вікна (близько 4,5 км) і досягає значень характерних для ії нижньої частини на глибинах близько 6 км. Водневий індекс демонструє поступове виснаження нафтового потенціалу порід від його вихідної величини, яка зберігається в інтервалі глибин від поверхні до приблизно 4,5 км до глибин близько 6 км, де його значення наближаються до мінімальних. В напрямку до більш внутрішніх структурно-тектонічних зон Карпат зменшується потужність відкладів менілітової світи. Зменшується і їхній нафтогенераційний потенціал, проте на значних територіях він залишається на середньому рівні.

Нижньокрейдові відклади шипотської і спаської світ широко розповсюджені в межах Зовнішніх Карпат і, будучи збагаченими розсіяною органічною речовиною, являють значний інтерес з точки зору оцінки ї нафтогенераційного потенціалу. На рис. 4 показана діаграма водневий індекс (НI) - температура піролізу при максимальному виході продуктів крекінгу керогену (Тмакс.), на якій показані результати дослідження зразків порід шипотської і спаської світ. Дослідженнями охоплені відклади спаської світи Скибової зони із відслонення в районі с. Тершів та із свердловини Максимівна-4 в інтервалі глибин від 4374 до 4429 м. Породи шипотської світи Чорногорської зони досліджені із відслонень в районі с.Гринява та із свердловини Гринява-1 в інтервалі глибин від 3496 до 3661 м. Породи шипотської і спаської світ вміщують кероген змішаного II і III типів і їхній нафтогенераційний потенціал можна класифікувати, як помірний до доброго. Величина нафтового потенціалу (S2) порід спаської світи досягає 9.38 мг вуглеводнів/г породи, а порід шипотської світи - 15.64 мг вуглеводнів/г породи. В поверхневих відслоненнях породи спаської світи демонструють дещо нижчу термальну зрілість, ніж породи шипотської світи. Перші залишаються термально незрілими, в той час як останні досягають верхньої частини нафтового вікна. Однак обидва комплекси порід у відслоненнях характеризуються низьким ступенем катагенетичної перетвореності, близьким до верхньої границі зони утворення нафти. 3 глибиною термальна зрілість відкладів суттєво зростає. Породи спаської світи із свердловини Максимівна-4 досягають середньої частини, а породи шипотської світи із свердловини Гринява-1 - нижньої частини зони утворення нафти. Результати наших досліджень показують, що відкла- 
ди шипотської і спаської світ характеризуються значним нафтовим потенціалом і за ступенем своєї термальної зрілості здатні генерувати вуглеводні. Отже, ці відклади, поряд із відкладами менілітової світи, яка $є$ основною нафтогенеруючою товщею Карпатської нафтогазоносної провінції, слід також вважати можливим джерелом вуглеводнів в регіоні.

Історія опускання відкладів карпатського флішу складається з двох основних стадій: 1) стадія опускання в результаті нагромадження молодших осадків в басейні седиментації; 2) синкінематична стадія. На протязі першої стадії відклади перебували лише під впливом діагенетичних процесів. Початок генерації вуглеводнів в товщі карпатського флішу пов'язаний в основному із другою стадією, на якій постседиментаційні перетворення порід і термальне дозрівання органічної речовини відбувалися завдяки глибокому опусканню флішових відкладів в результаті насувоутворення. В світлі сказаного Внутрішня зона Передкарпатського прогину є основною нафтоносною зоною Українських Карпат $з$ двох основних причин: 1) наявності потужних товщ менілітової світи; 2) складної насувної будови, завдяки якій ці відклади залягають в широкому діапазоні глибин, що включає в себе зону утворення нафти.

Широке площинне розпоширення олігоценових і нижньокрейдових відкладів та їх значна потужність вказують на можливість їх участі у формуванні нафтогазових систем на всій території Зовнішніх Карпат, включаючи райони, які ще не охоплені детальними пошуково-розвідувальними роботами на нафту і газ.

Силурійські чорносланцеві відклади досягають значної потужності і мають широке просторове поширення у фундаменті Передкарпатського прогину. Вони відділені від вищезалягаючих мезо-кайнозойських відкладів значною стратиграфічною та термальною незгідністю і могли б являти собою складову частину окремої нафтогазової системи, відмінної від молодших нафтогазових систем Карпатського регіону. Проте, одержані нами попередні дані геохімічних досліджень цих відкладів у свердловині Іспас-1 на Покутті показали, що вони є термально перезрілими. Пік S2 не існує, а отже нафтогенераційний потенціал цих порід вичерпаний i, незважаючи на кероген морського походження, вони не здатні генерувати рідкі вуглеводні. Нами продовжується дослідження цих відкладів на інших площах і беручи до уваги обширну територію ї існування і складну будову домезозойського фундаменту, їх можлива участь в процесах утворення покладів вуглеводнів в регіоні не виключається.

Вміст $\mathrm{C}_{\text {орг }}$ у вендських аргілітах миньковецького горизонту становив від десятих долей до понад 1\%. Оскільки, зважаючи на докембрійський вік, ці породи можуть вміщувати лише кероген морського походження, їх вихідний нафтогенераційний потенціал міг бути суттєвим. Дослідження цих відкладів методом піролізу Rock-Eval демонструють невисокий ступінь постседиментаційної перетвореності порід. Параметр піролізу Тмакс.має величину $441^{\circ} \mathrm{C}$, індекс продуктивності дорівнює 0,14 . Отже, незважаючи на тривалу геологічну історію, тектонічна еволюція регіону не спричинилася до термального перезрівання цих порід. Ці дані показують, що відклади миньковецького горизонту у поверхневих відслоненнях демонструють ступінь постседиментаційної перетвореності порід, що відповідає верхній частині зони утворення нафти. На сьогоднішній день немає даних про можливість реалізації нафтогенераційного потенціалу цих порід. Проте, не слід цілком виключати того, що в певних місцях історія їх опускання і термального дозрівання в комбінації з іншими літологічними і тектонічними факторами могли сприяти проходженню процесів генерації вуглеводнів.

Підсумовуючи вищесказане, слід відмітити, що в стратиграфічному розрізі Західної України на різних вікових рівнях - від венду до міоцену, знаходиться ряд потужних товщ порід, збагачених розсіяною органічною речовиною, які являють собою потенційні нафто-газоматеринські відклади. Дослідження наймолодших з них - мезозой-кайнозойських, показали, що умови їх седиментації сприяли нагромадженню значних мас вихідної органічної речовини потенційно нафтогенеруючого генетичного типу. Мікробіологічні перетворення на стадії раннього діагенезу забезпечили формування високого вихідного нафтогенераційного потенціалу порід. Подальша катагенетична еволюція цих відкладів контролювала процеси генерації вуглеводнів. Результати дослідження як мезозой-кайнозойських, так і більш давніх чорносланцевих товщ, які наведені в даній роботі, необхідно брати до уваги при формуванні стратегії подальших пошуково-розвідувальних робіт на нафту і газ в регіоні. 
1. Габинет М.П., Мамчур Г.П. Изотопный состав углерода в карбонатах олигоценового флиша Карпат // Вопросы минералогии осадочных образований. - Уздво Льв. ун-та. 1970. - Вып. 8. - С. 119-124.

2. Досин Г.Д. Некоторые особенности условий седиментации олигоценовой эпохи в пределах внешнекарпатской геосинклинали // Материалы Х Конгр. Карп.-Балкан. геол. ассоц.: Седиментология. Секция 2. - Братислава, 1974. - С. 59-63.

3. Колтун Ю.В., Мамчур Г.П. Об условиях формирования олигоценовых отложений Карпат по данным изотопного состава углерода карбонатных минералов и органического вещества // Минерал. сб. 1988. - № 42, вып. 1. - С. 54-61.

4. Колтун Ю.В., Курилюк Л.В., Сеньковський Ю.М. Палеоокеанографічні умови нагромадження органічної речовини в осадках карпатського флішового басейну // Геологія і геохімія горючих копалин. - 1996. - № 1-2 (94-95). - С.9-15.

5. Колтун Ю.В. Генерація вуглеводнів у флішових відкладах Внутрішньої зони Передкарпатського прогину //
Геологія і геохімія горючих копалин. - 2000. - № 4. С. 26-33.

6. Сеньковский Ю.Н. Литогенез кремнистых толщ югозапада СССР. - Киев: Наук. думка, 1977. - 280 с.

7. Сеньковский Ю. Н. Палеоокеанография Карпатского мелового апвеллинга // Геол. журн. - 1978. - 38, № 6. - С. $54-64$.

8. Сеньковский Ю. Н., Глушко В. В., Сеньковский А. Ю. Фосфориты запада Украины. - Киев: Наук. думка, 1989. - 144 c.

9. Espitalie J., Deroo G., Marquis F. La pyrolyse Rock-Eval et ses applications.- Deuxieme partie // Rev. Inst. Franc. Du Petrole. - 1985. - Vol. 40, № 6. - P. 755-784.

10. Koltun, Y.V. Organic matter in Oligocene Menilite Formation rocks of the Ukrainian Carpathians: palaeoenvironment and geochemical evolution. Organic Geochemistry - 1992. - Vol.18. - P. 423-430.

11. Schlanger S.O., Jenkyns H.C. Cretaceous oceanic anoxic events: causes and consequences. Geologie en Mijnbouw. - 1976. - Vol. 55, № 3-4. - P. 179-184.

Institute of Geology end Geochemistry of Combustibles Minerals NAS Ukraine, Lviv, Ukraine Інститут геології і геохімії горючих копалин НАН України, м. Львів, Україна 